\title{
COMMENTS
}

\section{Remedies for Fraud on the Patent Office}

Upon application to the Patent Office and compliance with the requirements of the Patent Act, ${ }^{1}$ an inventor is granted ${ }^{2}$ the right to prohibit others from manufacturing, selling, or using an invention claimed in a patent. ${ }^{3}$ Although the Patent Office attempts to develop information relevant to each application, limited resources ${ }^{4}$ and lack of access to relevant unpublished data force it to rely heavily on information submitted by applicants. ${ }^{5}$ Even when disclosure is candid and complete, the Office sometimes issues patents that should not have been issued. The chances of error are obviously increased when an applicant

135 U.S.C. $\S 1$ et seq. (1970). The subject matter covered by the patent must be a "process, machine, manufacture, or composition of matter, or . . . improvement thereof," id. § 101, which is "new and useful," id., and not obvious from the prior art in the field, id. $\$ 103$. The applicant must be the first inventor and must not have lost or abandoned the right to a patent, id. §§ 102(c), (f). The application must describe the invention in sufficient detail to enable one skilled in the relevant art to make and use the invention, $i d . \S 112$, and the portion of the described matter that constitutes the invention must be distinctly claimed, id. $\S 112$. An applicant may appeal an initial rejection of his application through the Patent Office and, if necessary, to the courts, $i d$. \$§ 134, 141, 145 \& 146.

2 The Patent Office usually evaluates the merits of a patent application in ex parte proceedings. Ladd, Business Aggression Under the Patent System, 26 U. CHI. L. Rev. 353, 356 (1959). When it appears that two or more pending applications cover the same invention, the question of which applicant was the first inventor is decided in an adversary proceeding known as an interference. 95 U.S.C. \$ 135; 97 C.F.R. \$\$ 1.201, 1.212 (1973).

395 U.S.C. $\$ 154$ (1970). The grant must be temporary, U.S. CoNsT. art. I, \& 8, and currently extends for seventeen years. 35 U.S.C. $\$ 154$ (1970). A patent holder can issue licenses under a patent or transfer all rights by assignment of the patent. Id. $\S 261$; see Bement v. National Harrow Co., 186 U.S. 70, 88-89 (1902). Unless otherwise noted, this comment considers only original patentees. A patentee can enforce patent rights in an infringement action. The court can award various remedies: damages or treble damages for past infringement, 35 U.S.C. \$ 284; see American Safety Table Co. v. Schreiber, 415 F.2d 373 (2d Cir. 1969), Cert. denied, 396 U.S. 1038 (1970); an injunction against further infringement, 35 U.S.C. § 283; and, in exceptional cases, attorney's fees. $I d$. \& 285.

4 The situation has not changed appreciably since Learned Hand noted: "Examiners have neither the time nor the assistance to exhaust the prior art; nothing is more common in a suit for infringement than to find that all the important references are turned up for the first time by the industry of a defendant whose interest animates his search." Rosenberg v. Groov-Pin Corp., 81 F.2d 46, 47 (2d Cir. 1936). See generally Graham v. John Deere Co., 383 U.S. 1, 18 (1966); Norton v. Curtiss, 433 F.2d 779, 794 (C.C.P.A. 1970); Ladd, supra note 2.

5 See Ladd, supra note 2, at 356-57. 
deliberately or inadvertently conceals, misrepresents, or falsifies relevant information. ${ }^{6}$

Proof that a patent is invalid-that it should not have been issuedis a complete defense to an infringement action brought under that patent, ${ }^{7}$ but it is not a ground for an affirmative action for damages. The patentee thus retains undeserved gains reaped from an invalid patent prior to a judgment of invalidity. Moreover, the patent statutes generally do not penalize deliberate attempts to deceive the Patent Office $^{8}$ by misrepresenting, falsifying, or concealing relevant information. ${ }^{9}$

Under certain judicially created doctrines, fraud on the Patent Office is a ground for cancellation of a patent, ${ }^{10}$ a defense to an infringement suit, ${ }^{11}$ and an element of certain antitrust causes of action. ${ }^{12}$ This comment suggests that existing statutory and judicial sanctions provide inadequate deterrence and redress for fraud on the Patent Office and proposes several legal theories that offer more effective sanctions. ${ }^{13}$

6 "Fraud" in this comment is used to mean deliberate misrepresentation, falsification, or concealment of information with intent to deceive the Patent Office.

735 U.S.C. $\S \S 282(2), 282(3)$ (1970). The defense is predicated on the patentee's failure to comply with one or more of certain prerequisites of patentability. It is also possible, of course, to bring an action for a declaratory judgment that a specific patent is invalid. Declaratory Judgment Act, 28 U.S.C. \$§ 2201-02 (1970).

8 Whether negligence in disclosure should be sanctioned is beyond the scope of this comment, but that issue can be profitably contrasted with the effect of sanctions for fraud. Performance of the patent system's essential function of "promot[ing] the progress of science and the useful arts," U.S. ConsT. art. I, § 8, requires that a patent be of significant benefit to potential inventors. Severe sanctions for mere negligence could discourage holders of valid patents from initiating infringement suits and thus risking a declaration that the patent is invalid. This consideration argues against severe sanctions for invalidity that results from mere negligence, because the sanction would limit the patent's stimulus to invention. But the argument is not equally applicable to severe sanctions for fraud, because fraud requires deliberate misrepresentation, leaving the nonfraudulent patentee with less reason to fear application of the sanction.

9 Although disclaimer of invalid claims and reissue of a patent to correct defective claims or specifications are available only if the invalidity or defect axose "without any deceptive intention" by the patentee, 35 U.S.C. $\$ \$ 251,253$ (1970), denial of reissue to the fraudulent patentee merely prevents the regrant of patent rights that the law otherwise denies the would-be patentee because of fraud. Denial of disclaimer also fails to provide an adequate sanction. See note 24 infra.

10 See text and notes at notes 14-17 infra.

11 See text and notes at notes 18-27 infra.

12 See text and notes at notes 28-52 infra.

13 The fact that actions predicated on fraud on the Patent Office are rare has been viewed as evidence that this fraud is not a serious problem. Cochran, Historical Review of Fraud in Patent Procurement: The Standards and Procedures for Doing Business Before the Patent Office, 52 J. Pat. OFF. Soc'y 71, 76, 80 (1970); Joel, Fraud in the Procurement of a Patent, $49 \mathrm{~J}$. Pat. OFF. Soc'y 596, 605-06 (1967). This premise is questionable. See Ram, Patent Fraud: A New Defense?, 54 J. PAT. OFF. Soc'y 363, 371 (1972). Even if it is correct, 


\section{Present Remedies}

A. The Cancellation Suit

The federal government has the right, inherent in its constitutional power to grant patents, to sue for cancellation of a patent for fraud in its procurement. ${ }^{14}$ Cancellation terminates patent rights $a b$ initio $;^{15}$ the patentee can no longer sue to enforce patent rights, and licensees are entitled to recoup royalties paid prior to cancellation.

Private parties cannot sue for cancellation, ${ }^{16}$ and the government rarely seeks this remedy. ${ }^{17}$ Cancellation is therefore an inadequate procedure for remedying and deterring patent fraud.

\section{B. The Unenforceability Defense}

Precision Instrument Manufacturing Co.v. Automotive Maintenance Machinery Co. established that fraud in the procurement of a patent is

however, the proposition supports this comment's view that available remedies provide insufficient incentive to private actions for fraud.

14 United States v. American Bell Tel. Co., 128 U.S. 315 (1888); United States v. Gunning, 18 F. 511 (C.C.S.D.N.Y. 1883).

16 United States v. Hartford-Empire Co., 73 F. Supp. 979 (D. Del. 1947).

16 Mowry v. Whitney, 81 U.S. 434 (1871).

17 The government has sued for cancellation of a fraudently procured patent only ten times. United States v. American Bell Tel. Co., 167 U.S. 224 (1897); United States v. American Bell Tel. Co., 128 U.S. 315 (1888); United States v. Saf-T-Boom Corp., 431 F.2d 737 (8th Cir. 1970); United States v. Marifarms, Inc., 345 F. Supp. 858 (D. Del. 1972) (preliminary injunction proceeding); United States v. Standard Elec. Time Co., $155 \mathrm{~F}$. Supp. 949 (D. Mass. 1957); United States v. Hartford-Empire Co., 73 F. Supp. 979 (D. Del. 1947); United States v. Cold Metal Process Co., 62 F. Supp. 127 (N.D. Ohio 1945); United States v. Colgate, 21 F. 318 (C.C.S.D.N.Y. 1884); United States v. Gunning, 18 F. 511 (C.C.S.D.N.Y. 1883); Attorney General ex rel Hecker v. Runford Chem. Works, 32 F. 608 (C.C.D.R.I. 1876). United States v. Fraser, 22 F. 106 (N.D. Ill. 1884), was dismissed as only colorably brought in the name of the United States. Some cases, of course, may have been settled before judgment and are thus unreported. Moreover, the government has only once invoked 18 U.S.C. $\S 1001$ (1970), which provides criminal penalties for fraud on a government agency, for fraud on the Patent Office. Mas v. United States, 151 F.2d 32 (D.C. Cir.), cert. denied, 326 U.S. 776 (1945). Senator Birch Bayh, introducing legislation directed at fraud on the Patent Office commented that despite section 1001, "little law enforcement action has been taken against such fraudulent conduct." 147 PateNT Trademark \& CopYRrGHT J. A-5 (Oct. 4, 1973).

It is uncertain whether the Federal Trade Commission will take significant action under American Cyanamid Co., 63 F.T.C. 1747, 1857-62 (1963), rev'd on other grounds, American Cyanamid Co. v. FTC, 363 F.2d 757 (6th Cir. 1966), in which it was held inter alia that enforcement of rights conferred by a fraudulently procured patent could be an unfair competitive practice under the Federal Trade Commission Act $\S 5,15$ U.S.C. $\$ 45$ (1970). Private parties cannot sue under the American Cyanamid doctrine; the Federal Trade Commission Act, $i d$. $\$ \S 41-58$ (1970), is not an antitrust law within the meaning of $i d$. $\$ 15(1970)$, and thus does not come under the provision authorizing private treble damage suits for violation of the antitrust laws, id. $\S 12$. See Lippa's, Inc. v. Lenox, Inc., 305 F. Supp. 182, 186 (D. Vt. 1969). See also Nashville Milk Co. v. Carnation Co., 355 U.S. 373, 374-76 (1958). 
a defense to an infringement suit brought under that patent because fraud renders the patent unenforceable. ${ }^{18}$ Although language in the Precision Instrument opinion provides a basis for extensive application of the doctrine, ${ }^{19}$ subsequent cases have differed about whether the defense may be predicated on nonmaterial misrepresentations ${ }^{20}$ or on

18324 U.S. 806 (1945). Although the defense is based on the equitable doctrine of unclean hands, it defeats claims for damages as well as claims for injunctive relief. Id; Monsanto Co. v. Rohm \& Haas Co., 312 F. Supp. 778, 781 (E.D. Pa. 1970) (by implication), aff'd, 456 F.2d 592 (3d Cir. 1972). Courts sometimes characterize the assertion of fraudulent procurement as a challenge to the validity of a patent. E.g., Walker Process Equip., Inc. v. Food Mach. \& Chem. Corp., 382 U.S. 172, 176 (1965).

19 "The far-reaching social and economic consequences of a patent, therefore, give the public a paramount interest in seeing that patent monopolies spring from backgrounds free from fraud or other inequitable conduct . . . 324 U.S. 806, 816 (1945). Thus, the doctrine apparently encompasses some inequitable conduct not rising to the level of fraud. Carter-Wallace, Inc. v. Davis-Edwards Pharmacal Corp., 443 F.2d 867 (2d Cir. 1971); Corning Glass Works v. Anchor Hocking Glass Corp., 253 F. Supp. 461 (D. Del. 1966).

20 One line of cases holds that fraud renders a patent unenforceable only if the fraud was material in the sense that, but for the fraud, the patent would not have been issued. Henkels \& McCoy, Inc. v. Elkin, 316 F. Supp. 303, 309 (W.D. Pa. 1970) (dictum-patent was held invalid); Monsanto Co. v. Dawson Chem. Co., 312 F. Supp. 452, 463 (S.D. Tex. 1970); Waterman-Bic Pen Corp. v. W.A. Sheaffer Pen Co., 267 F. Supp. 849, 856 (D. Del. 1967); Baldwin-Lima-Hamilton Corp. v. Tatnall Measuring Sys. Co., 169 F. Supp. 1, 24-25 (E.D. Pa. 1958); Tate Eng'r, Inc. v. United States, 477 F.2d 1336, 1345 (Ct. Cl. 1973).

Other cases suggest that a patent would be unenforceable if the fraud might have caused the issuance of the patent. Trio Process Corp. v. L. Goldstein's Sons, Inc., 461 F.2d 66, 73 (3d Cir. 1972) (dictum implied by treatment of Monsanto Co. v. Rohm \& Haas Co., 312 F. Supp. 778 (E.D. Pa. 1970); Corning Glass Works v. Anchor Hocking Glass Corp., 253 F. Supp. 461, 470-71 (D. Del. 1967); Becton, Dickinson \& Co. v. Sherwood Medical Indus., Inc., 175 U.S.P.Q. 337, 345-46 (M.D. Fla. 1972); Penn Yan Boats, Inc. v. Sea Lark Boats, Inc., 175 U.S.P.Q. 260, 272 (S.D. Fla. 1972). SCM Corp. v. RCA, 318 F. Supp. 433, 448 (S.D.N.Y. 1970) explicitly rejects the material fraud standard. In Hazel-Atlas Glass Co. v. Hartford-Empire Co., 322 U.S. 238 (1944), in which fraud had been committed on a court deciding a patent case, the Court found it unnecessary to "appraise the influence that the [fraud] exerted." Id. at 247.

Several cases suggest that serious lack of candor by a patent applicant renders a patent unenforceable. These cases focus on the patentee's conduct rather than the effect that the conduct might have had on Patent Office action. Precision Instrument Mfg. Co. v. Automotive Maintenance Mach. Co., 324 U.S. 806, 818 (1945) ("Public interest demands that all facts ... be submitted ... to the Patent Office, which can then pass upon . . . the evidence."); See also Monsanto Co. v. Rohm \& Hass Co., 456 F.2d 592, 598-99 (3d Cir. 1972); Beckman Instruments, Inc. v. Chemtronics, Inc., 428 F.2d 555, 565 (5th Cir. 1970) (also reported in 439 F.2d 1369) (" 'uncompromising duty' of good faith disclosure'); Corning Glass Works v. Anchor Hocking Glass Corp., 253 F. Supp. 461, 471 (D. Del. 1967); Abington Textile Mach. Works v. Carding Specialists (Canada) Ltd., 249 F. Supp. 823, 839-40 (D.D.C. 1965) (dictum).

In several cases that require proof of material fraud a "relevant information" standard would have led to the same result. For example, in Monsanto Co. v. Dawson Chem. Co., 312 F. Supp. 452, 463 (S.D. Tex. 1970) (material fraud requirement), the patentee's fraud was described as "a small corner of a broad picture" and in Baldwin-Lima-Hamilton Corp. v. Tatnall Measuring Sys. Co., 169 F. Supp. 1, 25 (E.D. Pa. 1958) (material fraud requirement), it was characterized as "an insignificant part of the argument." 
misrepresentations made without deliberate intent to deceive. ${ }^{21}$

A material misrepresentation requirement calls for proof that, on the true facts, the patent should not have been issued. Presumably, a meritorious patent application will be approved at some point in the issuance process; thus, fraud in such a patent application is not a material cause of issuance. This requirement sharply limits the value of the defense of unenforceability as a sanction for fraudulent procurement of a patent. ${ }^{22}$

The defendant in an infringement action has no additional incentive to prove material fraud, because proof that the patent should not have been issued (irrespective of whether issuance is due to fraud) is in itself a complete defense to an infringement action..$^{23}$ Furthermore, the sanctions imposed on the patentee for fraud and for mere invalidity are identical. ${ }^{24}$

Even if materiality is not an element of the defense, unenforceability provides neither an adequate remedy nor an effective deterrent. ${ }^{25} \mathrm{Un}$ -

21 Although there are few cases in point, it is apparently unnecessary for the defense to prove that the patent applicant has acted with actual knowledge that the representations to the Patent Office were false or misleading. "[G]ross negligence as to . . truth" may suffice, Norton v. Curtiss, 493 F.2d 779, 796 (G.C.P.A. 1970), as may recklessness, Baldwin-Lima-Hamilton Corp. v. Tatnall Measuring Sys. Co., 169 F. Supp. 1, 24-25 (E.D. Pa. 1958) (by implication). In Precision Instrument Mfg. Co. v. Automotive Maintenance Mach. Co., 324 U.S. 806, 817 (1945), where applicant had failed to disclose certain facts, the Court seemed unwilling to draw fine distinctions as to whether the applicant knew the facts or strongly suspected them.

Nonetheless, a good faith effort to disclose all material believed to be pertinent may excuse a failure to disclose relevant material. Scott Paper Co. v. Fort Howard Paper Co., 432 F.2d 1198, 1204-05 (7th Cir. 1970), cert. denied, 401 U.S. 913 (1971). But see note 20 stipra.

22 See text and notes at notes $38-44$ infra.

23 See text and note at note 7 supra.

24 Statutory provisions concerning the availability and effect of disclaimer of invalid claims apply only to claims made "without any deceptive intention." A patent in which a claim is both invalid and fraudulent is not covered by these statutory provisions and is subject to the common law rule that the invalidity of any one claim of a patent renders all other claims of that patent void. See Rearney \& Trecker Corp. v. Giddings \& Lewis, Inc., 452 F.2d 579, 596 (7th Cir. 1971); Chromalloy Am. Corp. v. Alloy Surfaces Co., 339 F. Supp. 859, 875-76 (D. Del. 1972).

This common law sanction for fraud is arbitrary in its operation. First, the harm caused by the fraudulent claim is measured by its commercial success, but the severity of the sanction depends on the commercial success of the other claims. Since different claims may vary in commercial success, the sanction could be less severe than the initial harm. Second, even if the severity of the sanction approaches the severity of the initial harm to competitors, the common law rule does not effectively redress the harm to an alleged infringer. Third, although the value a patentee has gained from a fraudulent claim increases as the term of the patent expires, the severity of the sanction diminishes because the voided claims have a shorter term to run.

25 Cf. Rosenberg, The Assertion of a Fraud Upon the Patent Office as a Means of De- 
enforceability fails to redress the harm caused by the invalid patent prior to adjudication; the patentee retains prior profits made through use of the patent rights. The unenforceability defense also fails to deter the patent applicant who could not, on the actual facts, procure a patent; misrepresentation is $\operatorname{costless}^{28}$ and may yield a patent that produces gains until a court determines that it was procured by fraud. ${ }^{27}$

\section{The Antitrust Sanction}

An effective remedy for fraud on the Patent Office would redress harm caused by the fraud by requiring the patentee to disgorge profits obtained through the use of the patent prior to a declaration of invalidity. Indeed, to deter fraud the expected damages must exceed the expected gains to the patentee from fraud. In Walker Process Equipment, Inc. $v$. Food Machinery \& Chemical Corp., ${ }^{28}$ the Supreme Court indicated that such a remedy might be available to private parties under section 2 of the Sherman Act. ${ }^{29}$ Although conduct otherwise violative of the antitrust laws is normally protected from prosecution by a patent, ${ }^{30}$ the Court held in Walker Process that there is no immunity to a charge of monopolization under section 2 of the Sherman $\mathrm{Act}^{31}$ if the patent was obtained by fraud on the Patent Office. ${ }^{32}$

The Walker Process doctrine has been characterized as the first effective weapon against fraudulent procurement..33 This description is overly optimistic; claims or counterclaims under the doctrine have

feating the Patent Monopoly, 50 J. Par. OFF. Soc'y 455, 479 (1968) (suggesting that the remedies available prior to the Walker Process doctrine, see text and notes at notes 28-32 infra, comprised only modest protection against fraud on the Patent Office).

26 Funds invested in exploitation of a fraudulently procured patent are lost when the patent is declared unenforceable. Strictly speaking, however, the fraud does not cause this loss, but only makes possible an improvident investment.

27 The suggestion in Nashua Corp. v. RCA, 307 F. Supp. 152, 158 (D.N.H. 1969), that a licensee may, upon proving that a patent is unenforceable for fraud, recoup royalties paid under the agreement is unsupported and unprecedented dictum. A holding to the same effect was reversed in Troxel Mfg. Co. v. Schwinn Bicycle Co., 465 F.2d 1253 (6th Cir. 1972). 28382 U.S. 172 (1965).

2915 U.S.C. \& $2(1970)$.

30382 U.S. at 176. United States v. Line Material Co., 333 U.S. 287, 309 (1948) (Sherman Act); United States v. Parker-Rust-Proof Co., 6I F. Supp. 805, 812 (E.D. Mich. 1945) ("antitrust laws"). But a "patent . . . does not give the patentee any exemption . . . beyond the limits of the patent monopoly." United States v. Singer Mfg. Co., 374 U.S. 174, 196-97 (1963).

3115 U.S.C. \& 2 (1970).

32 An assignee of the patentee retains antitrust immunity unless it is shown that the assignee was aware of the patentee's fraud. 382 U.S. at $177 \&$ n.5, 179 (Harlan, J., concurring).

33 Rosenberg, supra note 25 , at $484-85$. 
failed in nineteen of twenty cases..$^{34}$ The doctrine has several critical problems that limit its effectiveness as a sanction for fraud.

1. The "Significant Competition" Limitation. The Walker Process sanction reaches only fraudulently procured patents that result in "monopoly" within the meaning of the antitrust laws. ${ }^{35}$ Since a patented invention may be subject to significant economic competition from substitute products, ${ }^{36}$ a patent monopoly is not necessarily a monopoly under section 2 of the Sherman Act. The significant competition restric-

34 A counterclaim under Walker Process was successful in Kearney \& Trecker Corp. v. Giddings \& Lewis, Inc., 452 F.2d 579 (7th Cir. 1971). In Acme Precision Prods., Inc. v. American Alloys Corp., 484 F.2d 1237 (8th Cir. 1973), a holding in favor of a Walker Process claimant was reversed for failure to prove monopolization. The remaining eighteen cases are: Agrashell, Inc. v. Hammons Prods. Co., 479 F.2d 269 (8th Cir. 1973); Catophote Corp. v. DeSoto Chem. Coatings, Inc, 450 F,2d 769 (9th Cir. 1971); Bendix Corp. v. Balan, Inc., 421 F.2d 809 (7th Cir. 1970); Donald F. Duncan, Inc. v. Royal Tops Mfg. Co., 381 F.2d 879 (7th Cir. 1967); Mueller Brass Co. v. Reading Indus., Inc., 352 F. Supp. 1357 (E.D. Pa. 1972); Alfred Dunhill of London, Inc., v. Kasser Distillers Prods. Corp., 350 F. Supp. 1341 (E.D. Pa. 1972); Udin v. J. Kaufman Iron Works, Inc., 342 F. Supp. 1090 (S.D.N.Y. 1972); Struthers Scientific \& Int'l Corp. v. General Foods Corp., 334 F. Supp. 1329 (D. Del. 1971); Beckman Instruments, Inc. v. Chemtronics, Inc., 328 F. Supp. 1132 (W.D. Tex. 1971); Enviro Air, Inc. v. United Air Specialists, Inc., 322 F. Supp. 633 (S.D. Ohio 1970) (plaintiffs' motion for summary judgment on a claim under Walker Process denied); SCM Corp. v. RCA, 318 F. Supp. 433 (S.D.N.Y. 1970); Brown v. Myerberg, 314 F. Supp. 939 (S.D.N.Y. 1970); Kolene Corp. v. Motor City Metal Treating, Inc., 307 F. Supp. 1251 (E.D. Mich. 1969); Carter-Wallace, Inc. v. Riverton Laboratories, Inc., 304 F. Supp. 357 (S.D.N.Y. 1969); Mercantile Nat'l Bank v. Quest, Inc., 303 F. Supp. 926 (N.D. IIl. 1969); Crown Mach. \& Tool Co. v. KVP Sutherland Paper Co., 297 F. Supp. 542 (N.D. Cal. 1968); Diamond Int'l Corp. v. Walterhoefer, 289 F. Supp. 550 (D. Md. 1968); Corning Glass Works v. Anchor Hocking Glass Corp., 253 F. Supp. 461 (D. Del. 1966).

Conclusions based on reported cases may be misleading since the great majority of private antitrust actions are dismissed pursuant to settlement. Posner, A Statistical Study of Antitrust Enforcement, 13 J. LAW \& Econ. 365, 382-83 (1970).

35 Some commentators have suggested that the patent monopoly be considered ipso facto a monopoly within the meaning of the Sherman Act. Adelman \& Brooks, The Integrity of the Administrative Process, Sherman Section 2 and Per Se Rules-Lessons of Fraud on the Patent Office, 55 J. PAT. OFF. Soc'Y 255 (1973). It should be evident, however, that some patents-for example, a patent on one of many equally efficient processes for producing a given end product-do not result in monopoly power. See note 36 infra.

36 United States v. E.I. Du Pont de Nemours \& Co., 351 U.S. 377 (1956), illustrates the distinction between control of a single product and control of a market. Although defendant Du Pont accounted for 75 percent of domestic cellophane sales by virtue of its almost exclusive knowledge of the process of manufacturing cellophane, the Court held that it had not monopolized in violation of section 2 of the Sherman Act. The opinion did not rest on Du Pont's lack of the 100 percent dominance that a patent on cellophane would have conferred; rather, the Court recognized that other flexible packaging materials were so similar to cellophane that the relevant market for a monopoly determination was the market for all flexible packaging materials. Du Pont's share of the sales of flexible packaging materials was too small to justify a conclusion that it had monopolized that market. 
tion on Walker Process is sensible-antitrust penalties should not be imposed on fraudulent patentees who have not caused harm of the degree and kind contemplated by the antitrust laws-but it is also a major limitation on the effectiveness of the sanction because few patents are basic enough to allow monopoly of an entire field. Most are for patentable but minor improvements on the prior art. Walker Process thus can neither redress the harm these patents cause a patentee's potential competitors nor force the patentee to disgorge the profits obtained under a fraudulent nonmonopolistic patent.

The Walker Process doctrine's inability to reach patents that are not monopolistic in the antitrust sense also weakens its force as a deterrent to fraudulent applications for patents that do not result in the degree of monopoly required by section 2 of the Sherman Act. The doctrine may fail to discourage fraud even in cases that might result in monopoly when the holder of a basic patent permits competing parties to manufacture and sell the patented invention. Significant price competition among infringers and licensees could negate the degree of monopoly essential to a Walker Process claim. ${ }^{37}$

2. The "Material Fraud" Limitation. Lower courts have consistently interpreted Walker Process to require a claimant to prove material fraud. ${ }^{38}$ The claimant must show that the patent should not have been issued and that the patentee's fraud was the cause of the error. In many cases, however, the cause of the error cannot be ascertained. Although certain statutory requirements for patentability are relatively objec-

87 It should also be noted that the existence of a licensee might negate a claim for attempting to monopolize. Nonetheless, infringers and licensees are harmed by the fraudulent patent; but for the patent, infringers would have been able to compete more vigorously, see note 47 infra, and licensees would have avoided royalty payments.

Of the twenty cases listed in note 34 supra, sixteen involved Walker Process counterclaims to infringement suits. This suggests either that infringers are the parties most likely to have sufficient financial interests to justify litigation, or that fraud is unlikely to be detected except in discovery during a suit brought on other grounds. Thus, Walker Process will be of little value if the existence of infringers precludes a successful claim. The other four cases involving original Walker Process claims are not necessarily evidence to the contrary; in each case the plaintiff raised additional claims. The reports do not indicate whether the Walker Process claims were added only after discovery disclosed facts indicating fraud.

38 E.g., Beckman Instruments, Inc. v. Chemtronics, Inc., 428 F.2d 555 (5th Cir. 1970); Corning Glass Works v. Anchor Hocking Glass Corp., 253 F. Supp. 461 (D. Del. 1966). But see C.B. HaMruRg, Patent Fraud and INEQuitable Conbuct \$ 4.01[3][g], at 4-42 (1973). See also cases cited at note 20 supra. This lower court interpretation of Walker Process is interesting in light of the Supreme Court's favorable citation in Walker Process of the language in Precision Instrument Mfg. Co. v. Automotive Maintenance Mach. Co., 324 U.S. 806 (1945), suggesting an extensive application of remedies for patent fraud. Walker Process Equip., Inc. v. Food Mach. \& Chem. Corp., 382 U.S. 172, 177 (1965) (citing the Precision Instrument language reprinted at note 19 supra). 
tive, ${ }^{39}$ the central question of whether a claimed invention is new and nonobvious leaves considerable room for the exercise of discretion"the [statutory test] . . . is but vaguely defined [and] highly subjective," 40 and often "what position the examiner would have taken had [the patentee] been candid with him remains a matter of speculation."41 The examiner is not required to give reasons for his decision, ${ }^{42}$ and the Patent Office forbids explanatory testimony by the examiners in private litigation. ${ }^{43}$ Thus, if sanctions are imposed only for material fraud, meritorious claims may be denied for failure of proof.

This problem of proof of material fraud is especially acute in light of the Walker Process monopoly requirement. The courts have noted that the commercial success of a patented invention is strong, though not conclusive, evidence that the invention was indeed patentable.44 Since monopolization implies commercial success, it indicates that fraud relevant to whether the patented invention was new, useful, or nonobvious was probably not material.

3. The Costs of Walker Process Litigation. The Walker Process claimant will incur expenses in addition to the notoriously high costs normally associated with antitrust litigation.45 A Walker Process claimant must show conduct by the patentee that meets a more narrow definition of fraud than that required for unenforceability. ${ }^{46}$ Moreover, to prove materiality the claimant must prove the patent's invalidity; experience in other contexts has shown that the expense can discourage litigation. ${ }^{47}$ Finally, the claimant must prove that use of the

89 See, e.g., 85 U.S.G. \& 102(b) (1970) (a patent shall not be issued if the invention was in public use or on sale in this country more than one year prior to the date of the patent application). Even here there is some subjectivity, for a "use" is not public if it is primarily for experimental purposes. Smith \& Griggs Mfg. Co. v. Sprague, 123 U.S. 249 (1887). See also Pickering v. Holman, 459 F.2d 403 (9th Cir. 1972).

40 Ladd, supra note 2 , at 355.

41 SCM Corp. v. RCA, 318 F. Supp. 433 (S.D.N.Y. 1970).

42 The examiner is required to give reasons for rejecting applications but not for approving them. 37 C.F.R. \$\& 1.106, 1.113(b) (1973).

43 SCM Corp. v. RCA, 318 F. Supp. 433, 448 (S.D.N.Y. 1970).

44 Graham v. John Deere Co., 383 U.S. 1, 17-18 (1966). But see Scott Paper Co. v. Fort Howard Paper Co., 432 F.2d 1198, 1203-04 (7th Cir. 1970), cert. denied, 401 U.S. 913 (1971); Corning Glass Works v. Anchor Hocking Glass Corp., 253 F. Supp. 461, 469 (D. Del. 1966).

45 See Kohn, Evaluation of an Antitrust Claim, Prospective Cost of Litigation, Standing to Sue and Preparation of Suit, 38 ANrrTusT L.J. 7, 10-13 (1969).

46 Beckman Instruments, Inc. v. Chemtronics, Inc., 428 F.2d 555, 567 \& n.27 (5th Cir. 1970).

47 The costs of a patent lawsuit "can overwhelm a defendant quite as much as losing it," and it is commonly recognized that some patentees "assert their patents not to vindicate their rights, but to harass competitors by burdensome patent infringement litigation or 
fraudulent patent generated the patentee's monopoly. ${ }^{48}$

Although the prospect of a significant recovery under the treble damage provisions of the Clayton Act ${ }^{49}$ may offset a claimant's reluctance to risk the major expense of a Walker Process claim, certain practical considerations vitiate the treble damages incentive.

First, the prospect of substantial recovery is of no value to a claimant who cannot afford the initial costs of litigation, ${ }^{50}$ and the claimant who can afford to litigate must discount the fruits of a successful claim by the probability of failure; the low success rate of Walker Process claims $^{51}$ dampens a claimant's incentive to litigate. Second, the

the threat of such litigation." Ladd, supra note 2, at 353-54. In addition to the direct expenses of litigation, an alleged infringer suffers diversion of customers while the litigation is pending since under 35 U.S.C. $\S 271$ (a) (1970), those who buy and either use or resell an infringing device are themselves liable as infringers. Potential customers, seeking to avoid a lawsuit or an adverse judgment or having a small financial interest that does not justify an investigation of the merits of an allegation of infringement, tend to buy from sources other than the allegedly infringing manufacturer. The resulting loss to a manufacturer may not be recoverable as a matter of law, even if the allegation of infringement proves false. Furthermore, diverted customers may not return to the alleged infringer after the claim of infringement is adjudicated or settled. An attempt to prevent customer diversion by agreeing to indemnify customers against possible liability under section 271(a) is problematical; potential customers may not be confident enough of the seller's financial condition to rely on the agreement. See Borkin, The Patent Infringement Suit: Ordeal by Trial, 17 U. CHr. L. REv. 634 (1950); Ladd, supra note 2, at 364 n.50, 373.

A Walker Process counterclaim may delay adjudication of the claim of infringement and thus increase the counterclaimant's losses from customer diversion. This difficulty can be avoided by reserving the counterclaim for a separate trial, but this has been done in only one case. Alfred Dunhill of London, Inc. v. Kasser Distillers Prod. Corp., 350 F. Supp. 1341, 1368-69 n.29 (E.D. Pa. 1972).

48 Although no case discusses the issue, a patentee who monopolized under a valid nonfraudulent patent would presumably retain antitrust immunity for that patent monoply while holding a second unrelated patent that had been fraudulently procured. Proof of the origin of monopolization would be difficult and expensive when only one of several interlocking patents was tainted by fraud, or when only one of several claims under a single patent was fraudulent. See Nashua Corp. v. RCA, 307 F. Supp. 152, 158 (D.N.F. 1969).

4915 U.S.C. \& 15 (1970).

50 The statutory provision allowing recovery of attorney's fees applies only to exceptional cases. 35 U.S.C. 285 (1970). Moreover, that provision does not operate "until after litigation has occurred, and the outlay required to try a lawsuit presenting validity issues is the factor which undoubtedly forces many alleged infringers into accepting licenses rather than litigating." Blonder-Tongue Laboratories, Inc. v. University of Ill. Foundation, 402 U.S. 313, 347-48 (1971).

51 See text and note at note 34 supra. Moreover, there is reason to believe that Walker Process claims are not settled as frequently as other private antitrust actions. Since a private antitrust action often follows successful prosecution by the government, Posner, supra note 34 , at 372 , the ability to plead the prior judgment as evidence of an antitrust violation, 15 U.S.C. $\S 16$ (1970), facilitates settlement of the claim. In patent fraud cases, however, the prior judgment is almost always unavailable, because the government rarely acts against fraud on the Patent Office. Moreover, if the government action is a cancellation suit, it cannot be pleaded as evidence under 15 U.S.C. $\$ 16$ (1970). 
claimant has unique incentives to settle and obtain a share of the monopoly profits by accepting a license under the fraudulent patent. If there are no other licensees, the patentee will be the claimant's only competitor. ${ }^{52}$ A settlement, though redressing the harm the licensee has suffered from the fraudulent patent, allows harm to others to continue because the patent remains valid and enforceable. The patentee and the licensee, in a two-seller market, can charge a higher price for the patented product than would prevail under full competition.

\section{Proposed Remedies for Fraud on the Patent Office}

Unlike the Walker Process doctrine, an effective remedy for fraudulent patent procurement should not be limited to monopoly markets, ${ }^{, 3}$ require proof of material fraud, ${ }^{54}$ or subject the claimant to excessive litigation costs. ${ }^{55}$ Unlike the defense of unenforceability, ${ }^{56}$ it should provide full compensatory damages to parties injured by patent fraud. Furthermore, an effective remedy should provide punitive damages to deter fraud. ${ }^{\mathrm{T}}$

\section{A. The Common Law Fraud Remedy}

Damages have neither been awarded nor demanded ${ }^{58}$ from the patentee in actions for fraud on the Patent Office other than antitrust actions. Courts, however, have long awarded both compensatory and punitive damages in other fraud cases. ${ }^{59} \mathrm{~A}$ common law fraud remedy in patent fraud actions could redress harm through compensatory damages and deter fraud by patent applicants through punitive damages.

Private suits for damages for patent fraud can meet the five requirements ${ }^{60}$ of the common law misrepresentation doctrine. ${ }^{61}$ First, patent

62 See Kennedy, Patent and Antitrust Policy: The Search for a Unitary Theory, 35 GEo. WASH. L. REv. 512, 532-33 (1967); Note, Improperly Procured Patents: FTC Jurisdiction and the Remedial Power, 77 Harv. L. Rev. 1505, 1511 (1964); cf. SENATE ANTTTRUST AND Monopoly Subcomm., S. ReP. No. 448, 87th Cong., 1st Sess. 145, 152-54 (1961).

53 See text and notes at notes 35-37 supra.

54 See text and notes at notes $38-14$ supra.

s5 See text and notes at notes 45-52 supra.

56 See text and notes at notes 18-27 supra.

57 A risk neutral patentee will engage in fraud only if the expected gains from a fraudulent patent application (including potential monopoly profits) exceed the expected costs (compensatory and punitive damages). The gains from fraud will never be less than compensatory damages, and may actually exceed them if some victims fail to recover or if the patentee reaps monopoly profits. Thus, without punitive damages there is no signifcant deterrent to fraud.

58 But see Corning Glass Works v. Anchor Hocking Glass Corp., 253 F. Supp. 461, 464 (D. Del. 1966).

59 See W. Prosser, Torts $\S 110$, at 735-96 (4th ed. 1971).

60 See id. § 105 , at $685-86$.

01 See id. \& 105, at 683-94. 
fraud by definition includes a false representation. ${ }^{62}$ The defrauding patentee knows that the representation is false and intends to induce the injured parties and putative plaintiffs-potential competitors, their customers, and the patentee's customers-to act or refrain from acting in reliance on the patent. ${ }^{63}$ That plaintiffs act in reliance on the fraud is established when the representation concerning patentability plays a substantial part in the competitors' decisions to stay out of the market, or in the customers' decisions to buy from the patentee and not from a competitor. ${ }^{64}$ Finally, the plaintiffs suffer actual damages as a result of the fraud, due to either higher prices (customers) or lost profits (competitors).

In decisions in other fields, courts have indicated the factors relevant to an award of punitive damages: the potency of other sanctions, the impact of the label "fraudulent" on the defendant's business, the danger that the size of the total award could not be controlled in a series of actions by different parties on the same fraud, and the availability of class actions, which render unnecessary the use of punitive damages to encourage litigation of small claims. ${ }^{85}$

Under these guidelines, punitive damages are appropriate in patent fraud cases. The impotence of present remedies has already been noted, ${ }^{66}$ a patentee will not suffer greatly from loss of a reputation for honesty, ${ }^{67}$ and the possibility of excessive damages is smaller under common law theories that give courts discretion to award less than the treble damages required in Walker Process cases. Punitive damages are thus appropriate, since they would perform a needed deterrent function and their negative aspects would be minimized. Class actions would presumably be available for patent fraud claims, and the joint interests of putative infringers would provide incentives both to dis-

62 See note 6 supra.

63 Although the misrepresentation is made directly to the Patent Office rather than to the injured parties, the patentee can be held liable under common law doctrine. When the plaintiff is an unidentified member of a group and the defendant has reason to expect that a member of the group will be reached and influenced by the fraud, the courts will impose liability for intentional deceit. Prosser, Misrepresentation and Third Persons, 19 VAND. L. REV, 231, 246 (1966).

The intent is not merely that the Patent Office grant a patent in reliance on the fraud; the patentee also intends that in reliance on the allegation and appearance of patentability customers and competitors will hesitate to infringe or challenge the fraudulently procured patent.

64 There is no common law requirement of 'but for' materiality. W. ProssER, supra note $59, \& 110$, at $714-15$.

65 deHaas v. Empire Petroleum Co., 435 F.2d 1223, 1229-32 (10th Cir. 1970) (securities fraud); Globus v. Law Research Serv., Inc., 418 F.2d 1276, 1283-86 (2d Cir. 1969) (same).

66 See text and notes at notes 14-52 supra.

67 At least the harm caused by loss of reputation is less than for securities dealers. See Globus v. Law Research Serv., Inc., 418 F.2d 1276, 1285 (2d Cir. 1969). 
cover fraud and to litigate claims. ${ }^{68}$ But even if these incentives could assure enforcement, punitive damages are necessary to make that enforcement effective

\section{B. Antitrust Remedies}

Under the Walker Process doctrine, a fraudulently procured patent does not protect a patentee from liability for monopolization under section 2 of the Sherman Act. ${ }^{69}$ This restriction on immunity to antitrust prosecution should be expanded to reach other provisions of the antitrust laws. The following sections critically examine several theories under which a patentee could be subjected to antitrust liability for a fraudulent patent.

1. Patents as Contracts in Restraint of Trade. A patent can be viewed as a contract between the patentee and the government with disclosure of the invention ${ }^{70}$ as consideration for a legally enforceable right to exclude others temporarily from its exploitation. Since a patent obviously restrains trade, it could qualify as a "contract . . . in restraint of trade" prohibited by section 1 of the Sherman Act. ${ }^{71}$ Extension of the Walker Process doctrine to section 1 of the Sherman Act would make antitrust sanctions available for use against fraudulently procured patents. Damages for fraud would run from the day the patent was issued.

Courts have not fully defined the term "contract" as used in the antitrust statute. ${ }^{2}$ Patents have occasionally been called contracts, but decisions in these cases have not turned on the description. ${ }^{73}$ Because characterization of a patent as a contract could have consequences be-

68 Defensive action based on these joint interests raises other problems. In one case, for example, a group of putative infringers agreed that each would contribute to the defense of any member of the group sued by the patentee for infringement. Although the court found the agreement unobjectionable, it held that an ancillary agreement that no member would accept or negotiate a license without first notifying the others violated section 1 of the Sherman Act. Jones Knitting Corp. v. Morgan, 244 F. Supp. 235 (E.D. Pa. 1965), rev'd on other grounds, 361 F.2d 451 (3d Cir. 1966).

00 See text and notes at notes 29-32 supra.

70 The public benefits from this disclosure in that the invention is available for public use after the patent expires. Furthermore, even before the patent expires the technology it discloses may stimulate further invention.

71 15 U.S.C. \& 1 (1970).

72 "[F]ormal contract principles should not be literally applied to ascertain if the particular conduct in question is within the framework of section 1." Pearl Brewing Co. v. Anheuser-Busch, Inc., 339 F. Supp. 945, 950 (S.D. Tex. 1972). Pearl Brewing, which goes as far as any case in stating the relevant test, attempts to determine whether there is a "collaborative element," a "common scheme," or "joint action." Id. at 951.

73 United States v. Mariforms, Inc., 345 F. Supp. 858, 861 (D. Del. 1972); United States v. Hartford-Empire Co., 73 F. Supp. 979, 981 (D. Del. 1947); Fried. Krupp A.-G. v. Midvale Steel Co., 191 F. 588, 594 (3d Cir. 1911). 
yond the context of fraud, it may be undesirable to suggest the characterization solely to provide a remedy for fraud on the Patent Office.

2. Licenses as Contracts in Restraint of Trade. An agreement by which one party contracts not to manufacture a given article, or to manufacture it only upon payment of a royalty, usually constitutes a restraint of trade. ${ }^{74} \mathrm{~A}$ patent license involving similar restraints is immune from antitrust prosecution because it partially waives the patentee's right to exclude competitors entirely; when complete exclusion is permissible, partial exclusion is, by comparison, an expansion of trade. ${ }^{75}$ Under an extension of the Walker Process doctrine, however, a fraudulently procured patent would no longer protect the license from prosecution under section 1 of the Sherman Act as a "contract in restraint of trade."

This approach would not significantly expand the sanctions for patent fraud. Only those harmed by antitrust violations may bring private actions for redress. ${ }^{76}$ Although the licensee and consumers of the patented item are damaged by restrictions on the licensee's ability to compete, unlicensed competitors prodded into investigating the history of the patent under the threat of an infringement suit are most likely to discover the fraud. These unlicensed competitors suffer injury because of the fraud, but they are not harmed by the licensee's impaired ability to compete. On the contrary, they benefit because the licensed competitor's prices must reflect the royalties required by the license. Thus, the parties most likely to discover the fraud are those who cannot, on this restraint of trade theory, bring an action based on the fraud because they have not been injured by the license contract.

3. Licenses as Perpetuations of Restraint of Trade. A patent license diminishes the possibility that the licensee will discover the fraud underlying the patent and bring it to the court's attention; thus, the license perpetuates the fraudulent patent. Agreements that deceive the Patent Office into issuing a patent violate the antitrust laws, ${ }^{77}$ and con-

74 Hazeltine Research, Inc. v. Zenith Radio Corp., 239 F. Supp. 51 (N.D. IIl. 1965), rev'd on other grounds, 388 F.2d 25 (7th Cir. 1967), aff'd in part, rev'd in part on other grounds, 395 U.S. 100 (1969); United States v. Huck Mfg. Co., 227 F. Supp. 791 (E.D. Mich. 1964), aff'd, 382 U.S. 197 (1965).

75 A. \&. E. Plastik Pak Co. v. Monsanto Co., 396 F.2d 710 (9th Cir. 1968).

76 I5 U.S.C. $\$ 15(1970)$.

77 American Cyanamid Co., 63 F.T.C. 1747 (1963) ("unfair competitive practice" under FTC Act), rev'd on other grounds, American Cyanamid Co. v. FTC, 363 F.2d 757 (6th Cir. 1966). See United States v. Singer Mfg. Co., 374 U.S. 174, 200 (1962) (White, J., concurring): "[C]ollusion to secure a [patent] monopoly grant runs afoul of the Sherman Act's prohibition against conspiracies in restraint of trade ...."

Some of the leading cases holding that fraud in the procurement renders a patent 
tracts that prolong a restraint of trade through licensing of fraudulent patents should be sanctioned as severely. The parties injured by an agreement that conceals patent unenforceability include all who have an interest in challenging the patent, especially alleged infringers. This theory would therefore provide alleged infringers an additional method to attack fraudulent patents. The gravamen of the claim would be that the patentee perpetuated a restraint of trade by issuing a license and thereby discouraging the licensee from discovering and revealing the patent fraud.

The sanction would be limited to a patentee who either knew that the patent was unenforceable or knew the facts leading to that legal conclusion when issuing the license, ${ }^{78}$ that is, a patentee who has deliberately committed fraud on the Patent Office that would render the patent unenforceable. If unenforceability does not require proof of material fraud, ${ }^{79}$ all the elements of unenforceability are within the fraudulent patentee's knowledge.

There are significant problems of proof in determining the appropriate amount of damages, especially if damages were to run from the date that, but for the license, the licensee would have obtained a judicial declaration of the invalidity of the patent. Of course, since the license is the agreement that effects perpetuation of the restraint of trade, the latter problem could be solved by measuring damages from the date the license was granted.

4. Exclusive Dealing. Consumers and sellers of infringing goods purchased from a patentee's unlicensed competitors are liable as infringers of the patentee's patent. ${ }^{80}$ If a patent is ostensibly valid, customers will often choose to buy from the patentee rather than an allegedly infringing seller to avoid this liability. In the case of a

unenforceable involved fraudulent agreements rather than unilateral fraud by the patent applicant. E.g., Precision Instrument Mfg. Co. v. Automotive Maintenance Mach. Co., 324 U.S. 806 (1945) (unclean hands); Hazel-Atlas Glass Co. v. Hartford-Empire Co., 322 U.S. 238 (1944). No court, in cases decided after Walker Process, has dealt with the argument that a fraudulent agreement would meet the "contract, combination, or conspiracy" requirement of section 1 of the Sherman Act. 15 U.S.C. \& 1 (1970).

78 This limitation is necessary to allow settlement of a patent dispute by issuing a license. When a fraudulent patentee contests a challenge to a patent, hope of success is based not on a belief in the validity of the patent but on the hope that the challenger will be unable to prove the underlying fraud. From the fraudulent patentee's viewpoint, the settlement of a patent dispute represents an arrangement to continue exploitation of a fraudulent patent, rather than a compromise of an unresolved dispute. Thus, application of antitrust sanctions to licenses under fraudulent patents will not deter attempts to settle bona fide disputes under nonfraudulent patents by issuing licenses.

79 See text and notes at notes 18-21 and 38-44 supra.

8035 U.S.C. § $271(\mathrm{a})$ (1970). 
fraudulently procured patent; sales to customers may violate the prohibition in section 3 of the Clayton Act against "a sale or contract for sale of goods ... [on the] ... understanding that the ... purchaser thereof shall not use or deal in the goods . . of a competitor . . of the ... seller, where the effect of such . . . understanding may be to lessen competition ...." 81

The requisite effect on competition under this provision of the Glayton Act is less than that required for monopolization under the Sherman Act. 82 The Clayton Act deals with a "substantial lessening" of competition and use of the word "may" indicates that a potential lessening may suffice. ${ }^{83}$ Furthermore, a patent "is at least prima facie evidence" of the power to cause this effect on competition "although in fact there may be many competing substitutes for the patented article."84 Relevant market inquiry would therefore be unnecessary when the Clayton Act is used to attack a fraudulently procured patent.

The "understanding" that a customer will not purchase the goods ${ }^{85}$ of a competitor is usually not explicit in sales agreements for patented goods, but may reasonably be read into the sale when the customer knows that the good is patented and that purchases from the patentee's competitor involve potential liability for infringement. ${ }^{86}$ This knowledge is usually present when the patentee informs the customer or the trade that the competitor is infringing, or when the patentee threatens litigation.

This remedy would be available to potential and actual purchasers and users of the patented good. Under an extension of Walker Process, this proposed antitrust remedy would reach only holders of fraudulently procured patents; bona fide patentees would be protected by the principle that protects a valid patent monopoly.

\section{CoNCLUSIONS}

Current remedies for fraud on the Patent Office-cancellation of the patent, the defense of unenforceability, and the Walker Process antitrust

8115 U.S.C. \$ 14 (1970).

82 Tampa Elec. Co. v. Nashville Coal Co., 365 U.S. 320, 335 (1961); Mercantile Nat'l Bank v. Quest, Inc., 303 F. Supp. 926, 935 (D. Ind. 1969); Fagan v. Sunbeam Lighting Co., 303 F. Supp. 356, 361 (S.D. IIl. 1969).

83 National Dairy Prod. Corp. v. FTC, 395 F.2d 517 (7th Gir. 1968), cert. denied, 393 U.S. 977 (1969).

84 Standard Oil Co. of Cal. v. United States, 337 U.S. 293, 307 (1949).

85 This remedy would not reach fraudulently procured process patents. Section 3 of the Clayton Act applies only to sales or to contracts for sale of "goods, wares, merchandise, machinery, supplies and other commodities." 15 U.S.C. \& 14 (1970).

8835 U.S.C. \& 271 (a) (1970). 
suit-are unable to deter patent fraud and redress effectively the harm caused by that fraud. This comment has proposed several approaches under the common law doctrine of misrepresentation and the antitrust laws that provide more effective deterrence and relief. Although each approach presents difficulties, together they may expand the category of potential plaintiffs, simplify the burden of proof, and permit recovery of full compensation and punitive damages.

Kenneth L. Spector 